\title{
Streamflow—Water Year 2020
}

\section{Introduction}

The maps and graphs in this summary describe national streamflow conditions for water year 2020 (October 1, 2019, to September 30, 2020 ) in the context of streamflow ranks relative to the 91-year period of water years 1930-2020, unless otherwise noted. The figures are based on observed data (U.S. Geological Survey, 2021c) from the U.S. Geological Survey (USGS) National Streamgage Network (U.S. Geological Survey, 2021a). The period of water years 1930-2020 was evaluated because the number of streamgages in the network before 1930 was too small to provide statistically significant data to compute meaningful statistics in most regions of the country.

In this summary, reference is made to the term "runoff," which is defined as the amount of water flowing through a stream divided by the drainage basin area of the stream. Runoff represents an equivalent depth of water over the basin. Normalizing the flow by dividing by drainage area results in quantities that can be compared from one area to another. In this summary, runoff for a specified period and geographic area is computed from all streamgages with complete streamflow records in the geographic area. In the figures, a rank of 1 indicates the maximum annual flow of all years analyzed, and a rank of 91 indicates the minimum annual flow of all years analyzed. Rankings of streamflow are grouped into much below normal, below normal, normal, above normal, and much above normal categories based on percentiles of flow (less than 10 percent, 10-24 percent, 25-75 percent, 76-90 percent, and greater than 90 percent, respectively;
U.S. Geological Survey, 2021b). Streamflow conditions for States or water-resources regions are presented in the text in order of ranking from maximum to minimum flow; a maximum or minimum flow rank is not shown when there are ties in the rankings. Some of the data used to produce the maps and graphs are provisional and subject to change.

\section{National Overview}

Annual runoff in the Nation's rivers and streams during water year 2020 (11.10 inches) was higher than the long-term (1930-2020) mean annual runoff of 9.40 inches for the contiguous United States (fig. 1). Nationwide, the 2020 annual average streamflow ranked the 10th highest out of the 91 years.

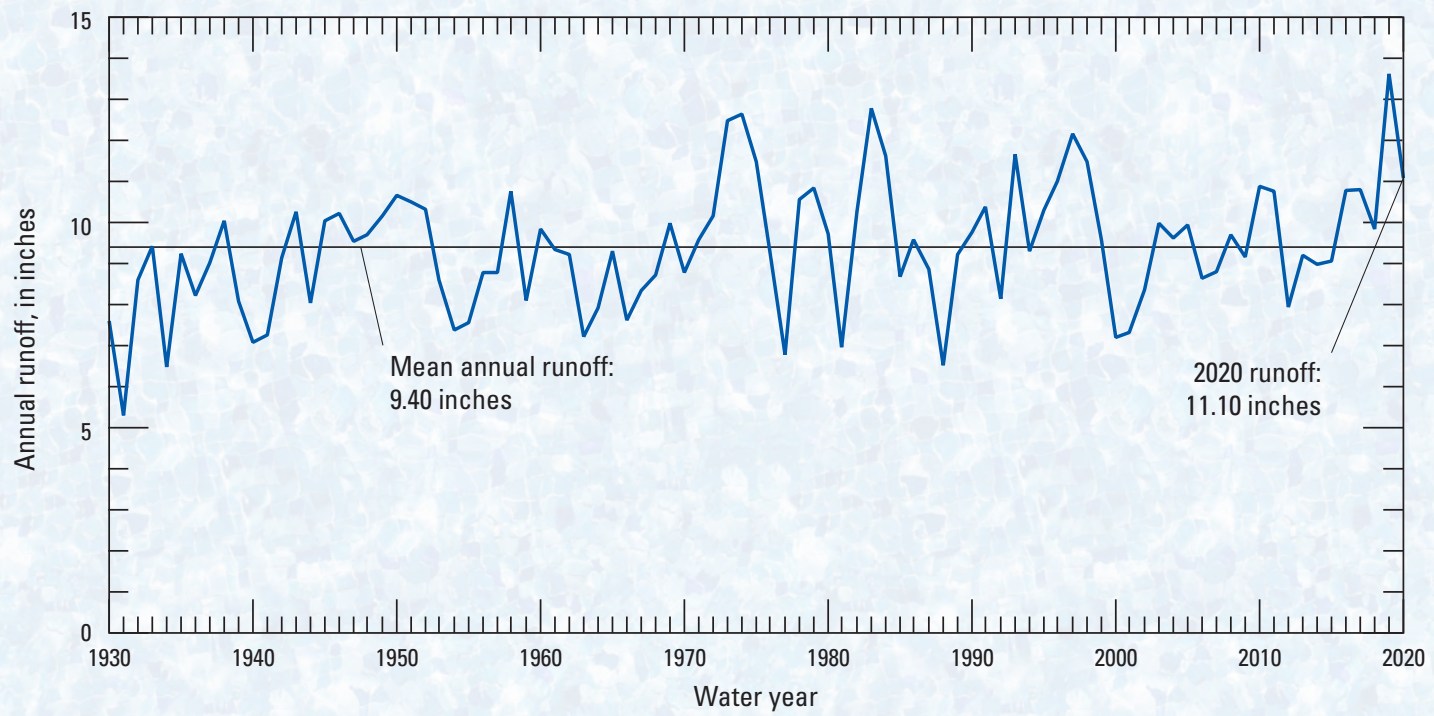

Figure 1. Annual runoff in the contiguous United States, water years 1930-2020. 


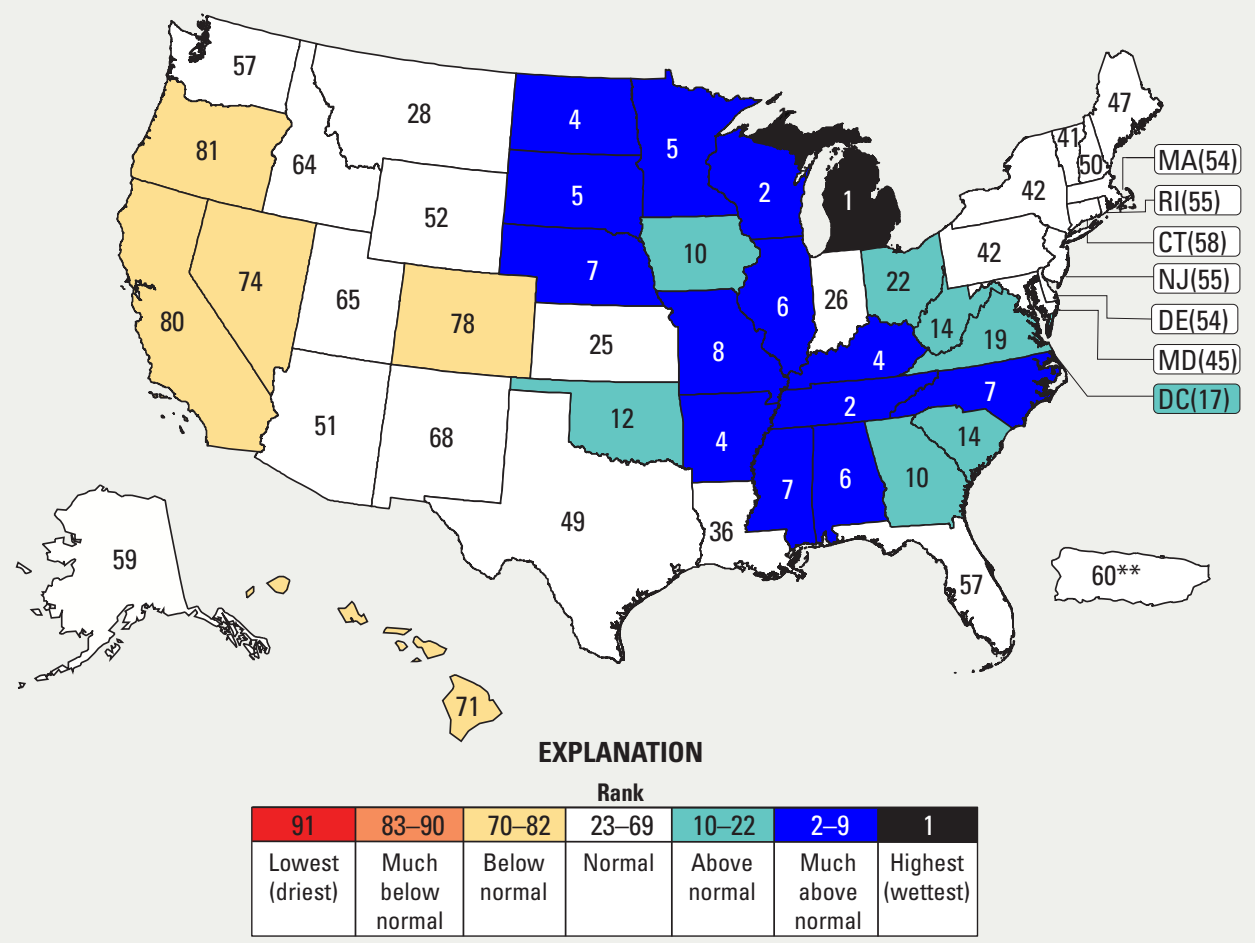

Figure 2. Statewide streamflow ranks of the United States for water year 2020 compared to mean annual streamflows for water years 1930-2020. [Some colors in the explanation may not be used on the map; ${ }^{*}$, for Puerto Rico combined with the Virgin Islands, 77 years of available data were used, and the rank was adjusted accordingly]

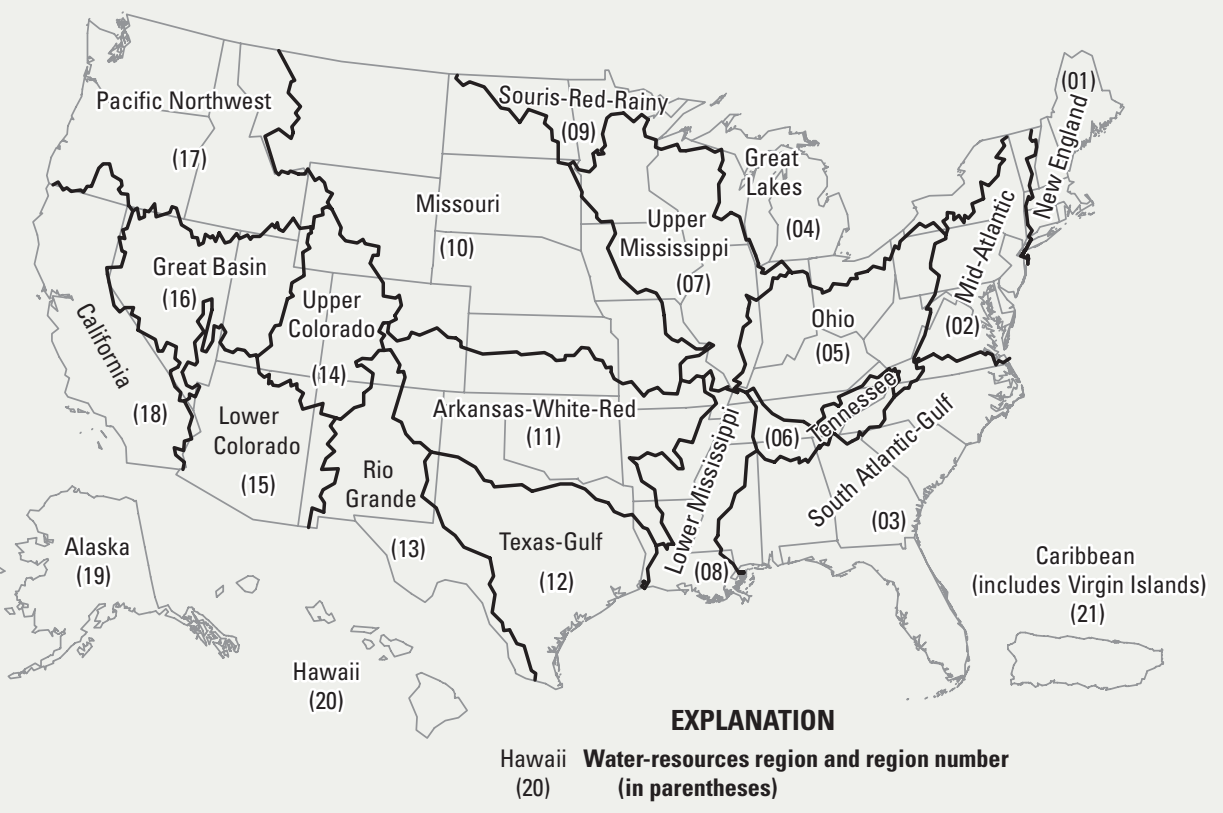

Figure 3. Water-resources regions of the United States.
Annual mean streamflow also was ranked by State, which in this summary includes the District of Columbia and Puerto Rico combined with the Virgin Islands. Streamflow was below normal in California, Colorado, Hawaii, Nevada, and Oregon (fig. 2). Streamflow was above normal in the District of Columbia, Georgia, Iowa, Ohio, Oklahoma, South Carolina, Virginia, and West Virginia. Streamflow was much above normal in Alabama, Arkansas, Illinois, Kentucky, Minnesota, Mississippi, Missouri, Nebraska, North Carolina, North Dakota, South Dakota, Tennessee, and Wisconsin. Record maximum streamflow was measured in Michigan.

\section{Regional Patterns}

The United States, the District of Columbia, and Puerto Rico combined with the Virgin Islands lie in 21 large drainages, or water-resources regions (fig. 3). These water-resources regions are based on surface topography and contain the drainage area of a major river; the combined drainage areas of a series of rivers, such as the Texas-Gulf region, which includes several rivers draining into the Gulf of Mexico; or the area of an island or island group. Water-resources regions provide a coherent, watershed-based framework for depicting streamflow variations. 


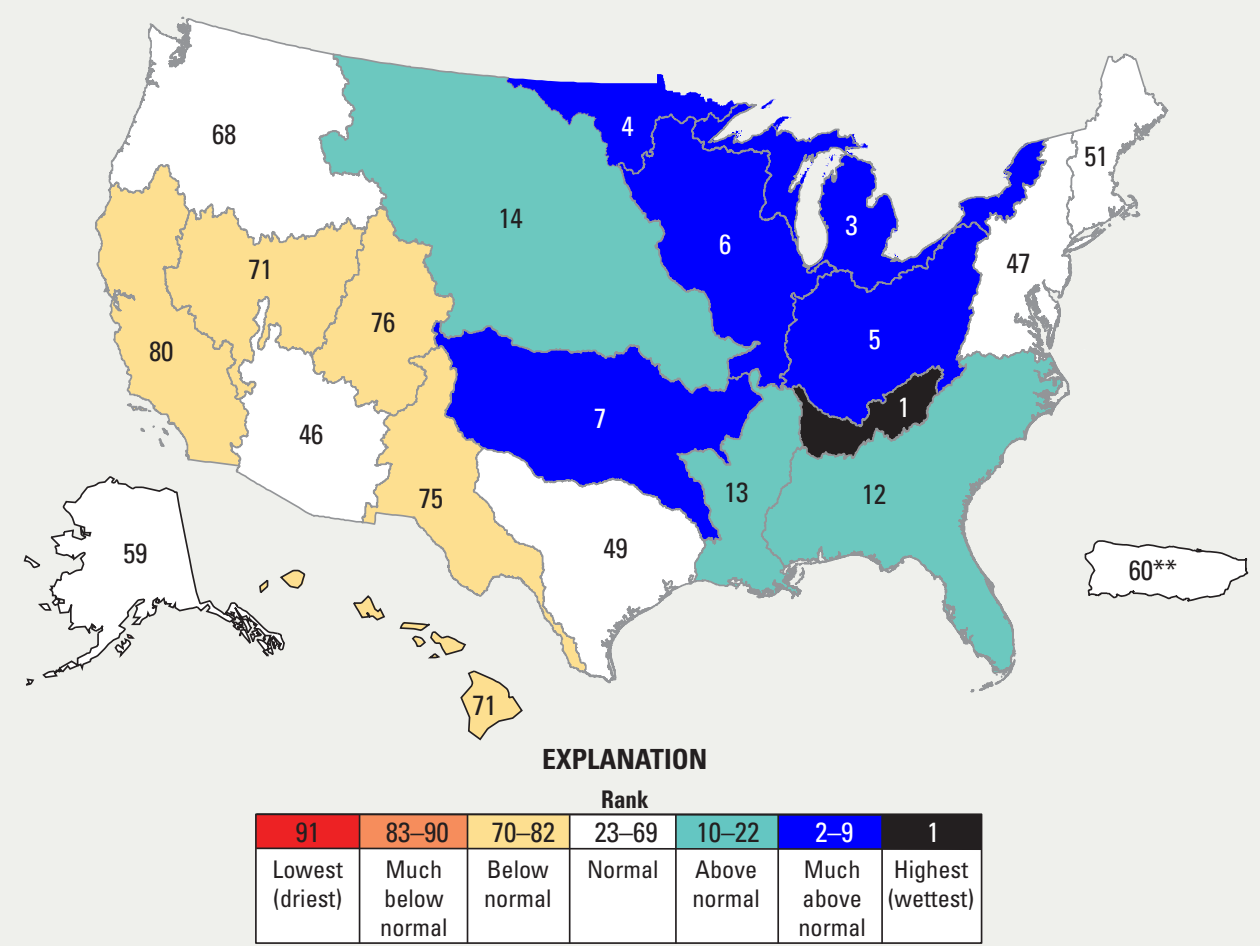

Figure 4. Regional streamflow ranks in the United States for water year 2020 compared to mean annual streamflows for water years 1930-2020. [Some colors in the explanation may not be used on the map; ${ }^{* *}$, for Puerto Rico combined with the Virgin Islands, 77 years of available data were used, and the rank was adjusted accordingly]

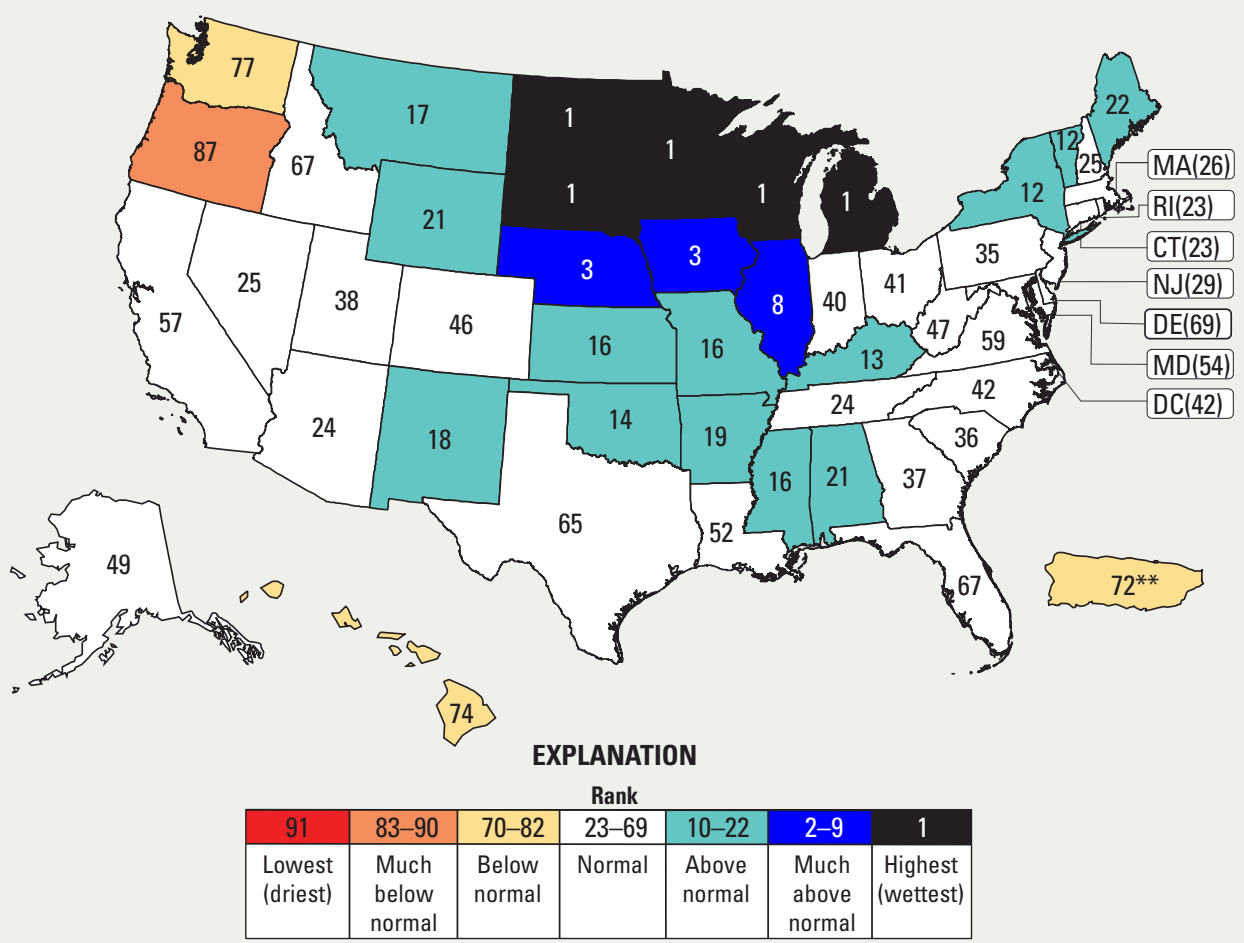

Figure 5. Autumn (October-December 2019) statewide streamflow ranks in the United States compared to mean quarterly streamflows for water years 1930-2020. [Some colors in the explanation may not be used on the map; ${ }^{* *}$, for Puerto Rico combined with the Virgin Islands, 77 years of available data were used, and the rank was adjusted accordingly]
Annual mean streamflow was ranked below normal levels in the California, Hawaii, Great Basin, Rio Grande, and Upper Colorado regions (fig. 4). Annual mean streamflow was ranked above normal in the Lower Mississippi, Missouri, and South Atlantic-Gulf regions. Streamflow was ranked much above normal in the ArkansasWhite-Red, Great Lakes, Ohio, Souris-Red-Rainy, and Upper Mississippi regions. Record maximum streamflow was measured in the Tennessee region.

\section{Seasonal Characteristics}

Autumn (October-December 2019) streamflow was ranked much below normal in Oregon (fig. 5). Streamflow was ranked below normal in Hawaii, Puerto Rico combined with the Virgin Islands, and Washington. Streamflow was ranked above normal in Alabama, Arkansas, Kansas, Kentucky, Maine, Mississippi, Missouri, Montana, New Mexico, New York, Oklahoma, Vermont, and Wyoming. Streamflow was ranked much above normal in Illinois, Iowa, and Nebraska. Record maximum streamflow was measured in Michigan, Minnesota, North Dakota, South Dakota, and Wisconsin. Nationwide, autumnseason streamflow ranked the highest out of 91 years. 


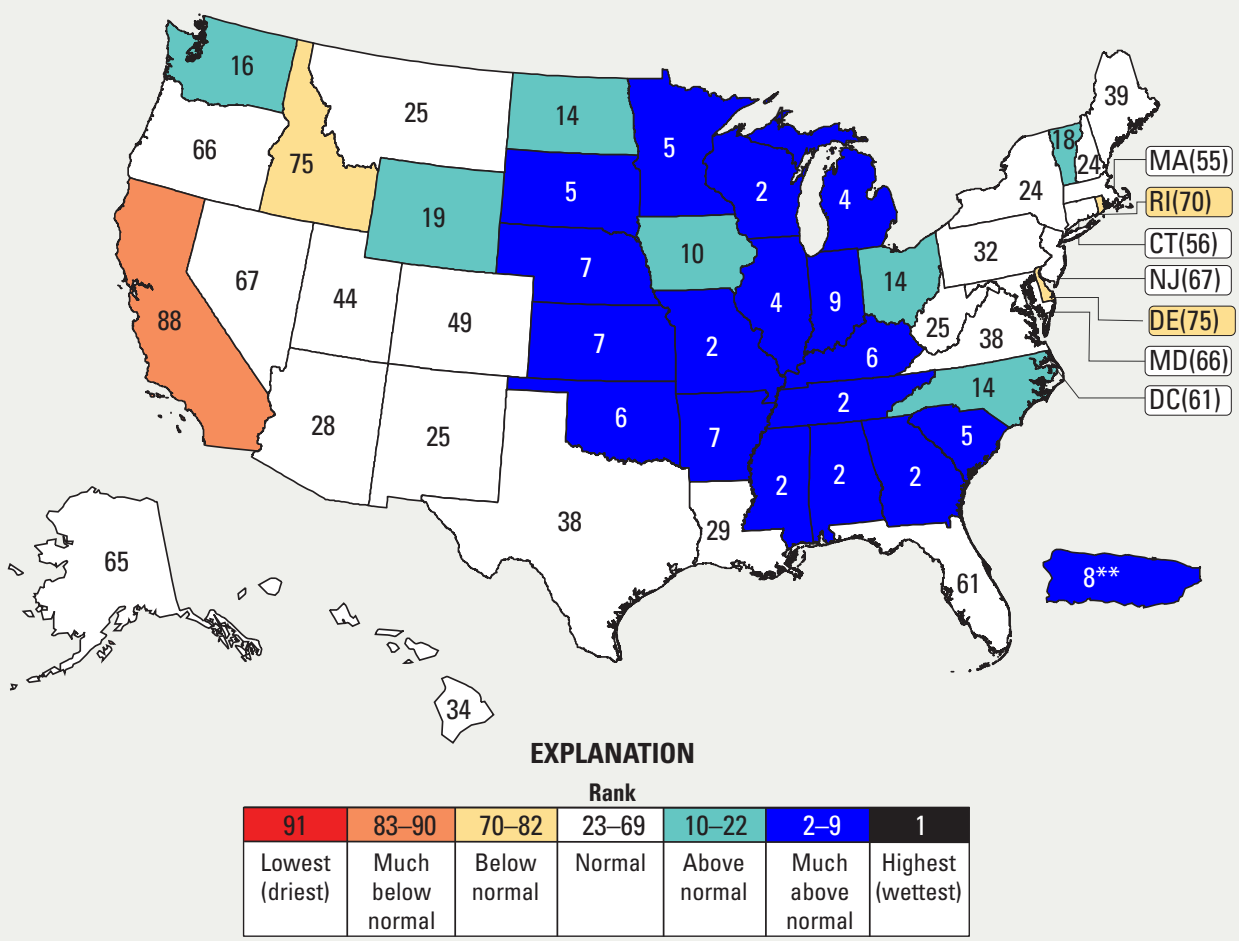

Figure 6. Winter (January-March 2020) statewide streamflow ranks in the United States compared to mean quarterly streamflows for water years 1930-2020. [Some colors in the explanation may not be used on the map; ${ }^{* *}$, for Puerto Rico combined with the Virgin Islands, 77 years of available data were used, and the rank was adjusted accordingly]

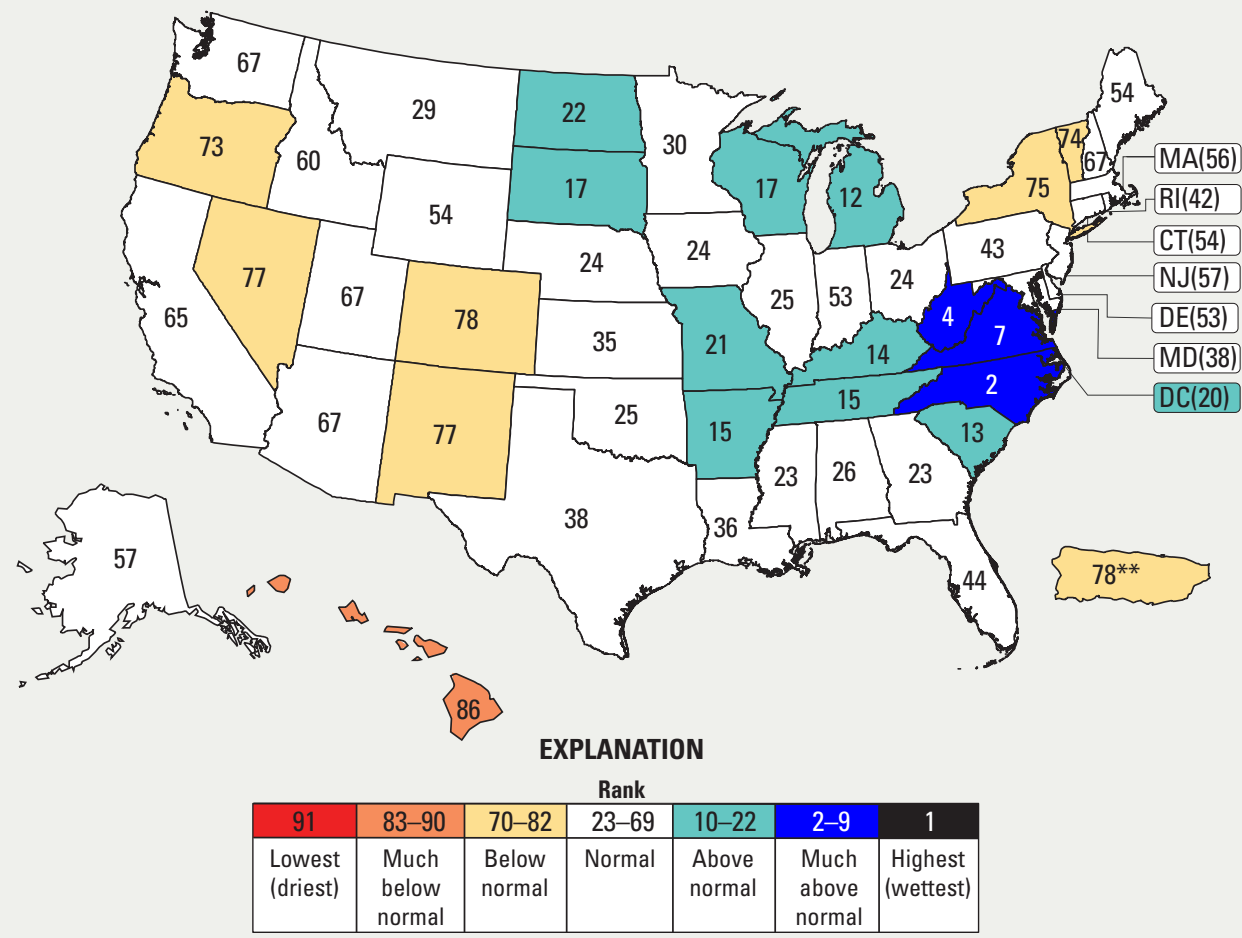

Figure 7. Spring (April-June 2020) statewide streamflow ranks in the United States compared to mean quarterly streamflows for water years 1930-2020. [Some colors in the explanation may not be used on the map; ${ }^{*}$, for Puerto Rico combined with the Virgin Islands, 77 years of available data were used, and the rank was adjusted accordingly]
Winter (January-March 2020) streamflow was ranked much below normal in California (fig. 6). Streamflow was ranked below normal in Delaware, Idaho, and Rhode Island. Streamflow was ranked above normal in Iowa, North Carolina, North Dakota, Ohio, Vermont, Washington, and Wyoming. Streamflow was ranked much above normal in Alabama, Arkansas, Georgia, Illinois, Indiana, Kansas, Kentucky, Michigan, Minnesota, Mississippi, Missouri, Nebraska, Oklahoma, Puerto Rico and the Virgin Islands, South Carolina, South Dakota, Tennessee, and Wisconsin. Nationwide, winterseason streamflow ranked the sixth highest out of 91 years.

Spring (April-June 2020) streamflow was ranked much below normal in Hawaii (fig. 7). Streamflow was ranked below normal in Colorado, Nevada, New Mexico, New York, Oregon, Puerto Rico combined with the Virgin Islands, and Vermont. Streamflow was ranked above normal in Arkansas, the District of Columbia, Kentucky, Michigan, Missouri, North Dakota, South Carolina, South Dakota, Tennessee, and Wisconsin. Streamflow was ranked much above normal in North Carolina, Virginia, and West Virginia. Nationwide, spring-season streamflow ranked the 34th highest out of 91 years. 


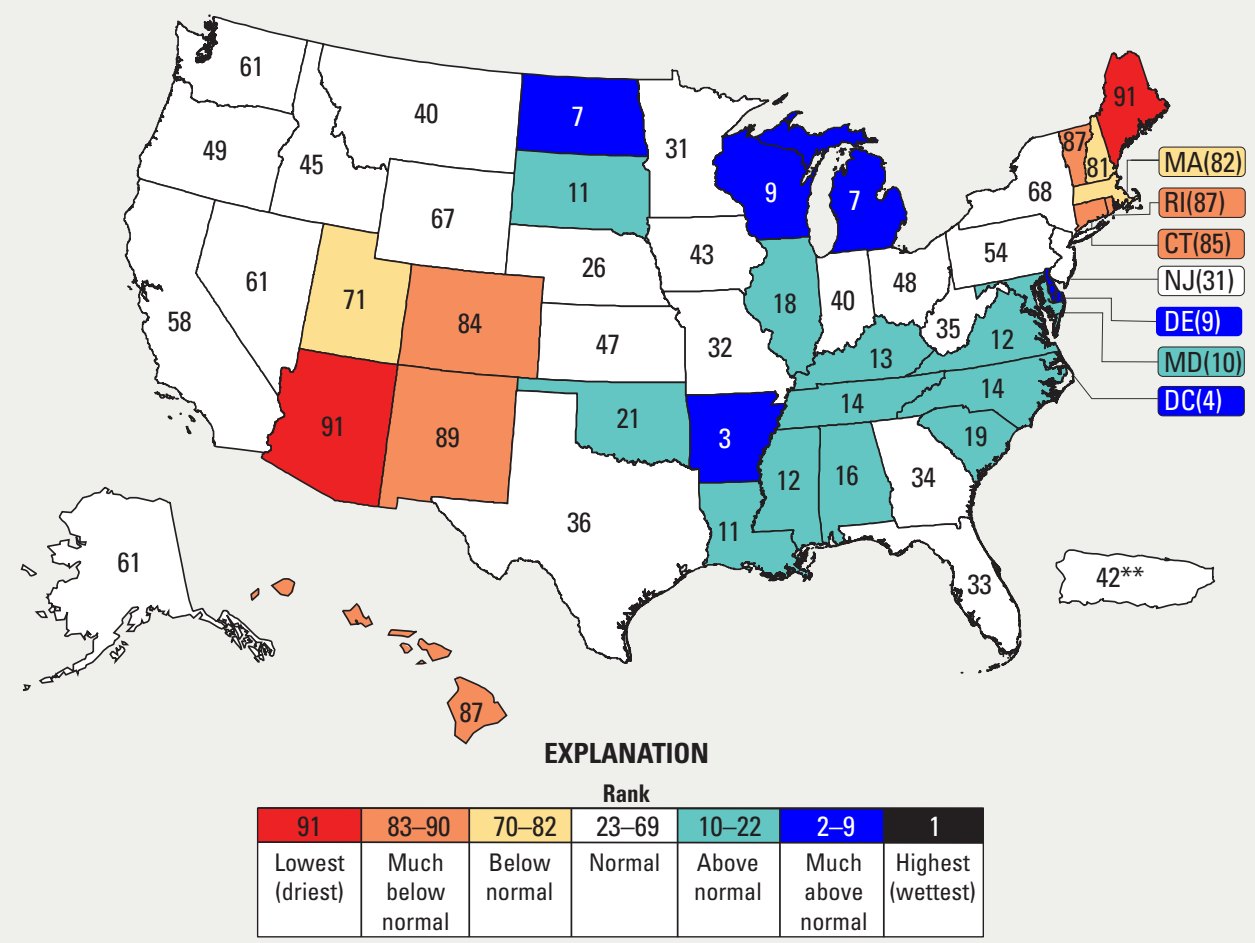

Figure 8. Summer (July-September 2020) statewide streamflow ranks in the United States compared to mean annual streamflows for water years 1930-2020. [Some colors in the explanation may not be used on the map; ${ }^{* *}$, for Puerto Rico combined with the Virgin Islands, 77 years of available data were used, and the rank was adjusted accordingly]

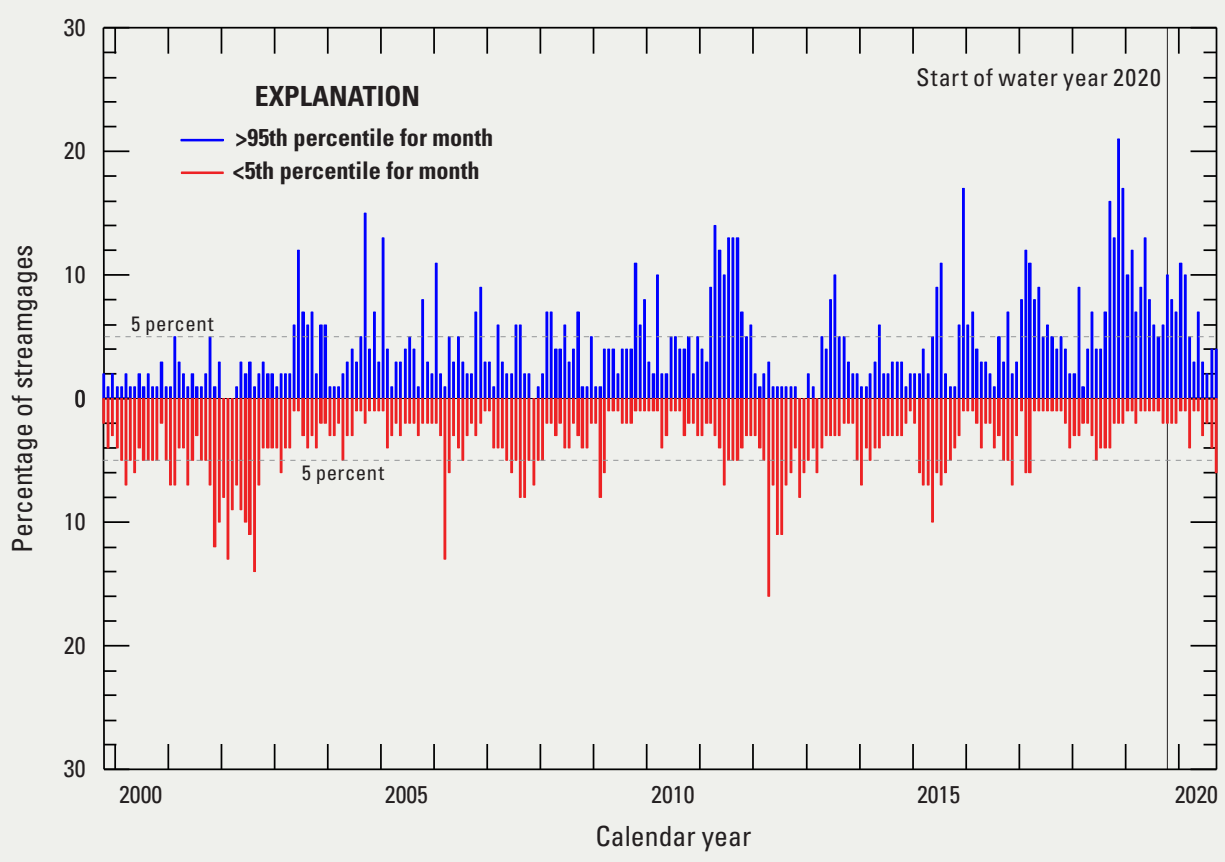

Figure 9. Percentage of streamgages with high and low monthly streamflow, October 1999September 2020.
Summer (July-September 2020) record minimum streamflow was measured in Arizona and Maine (fig. 8). Streamflow was ranked much below normal in Colorado, Connecticut, Hawaii, New Mexico, Rhode Island, and Vermont. Streamflow was ranked below normal in Massachusetts, New Hampshire, and Utah. Streamflow was ranked above normal in Alabama, Illinois, Kentucky, Louisiana, Maryland, Mississippi, North Carolina, Oklahoma, South Carolina, South Dakota, Tennessee, and Virginia. Streamflow was ranked much above normal in Arkansas, Delaware, the District of Columbia, Michigan, North Dakota, and Wisconsin. Nationwide, summer-season streamflow ranked the 25th highest out of 91 years.

\section{High and Low Flows}

Assuming individual streamgage data are independent of other streamgage data and are normally distributed, the monthly streamflow is expected to be high (greater than 95th percentile) at 5 percent of the streamgages and is expected to be low (less than the 5 th percentile) at 5 percent of the streamgages during any given month. The percentages of streamgages reporting high streamflow in six months of water year 2020 (October, November, and December 2019 and January, February, and May 2020) were greater than expected $(10,8,7,11$, 10, and 7 percent, respectively; fig. 9). In contrast, there was only one month (September 2020) with a greater-than-expected percentage of streamgages reporting low flow (6 percent). 


\section{Additional Information}

The USGS operated a nationwide network of more than 8,400 year-round, real-time streamgages in water year 2020. The real-time data from these streamgages are available at https://waterwatch.usgs.gov. The streamflow information used to prepare this summary also is used for water management, flood and drought monitoring, bridge design, and several recreational activities. To obtain realtime and archived streamflow data and information, visit the USGS National Water Information System database at https://doi.org/10.5066/F7P55KJN (U.S. Geological Survey, 2021c). The National Streamflow Network, which is part of the Groundwater and Streamflow Information Program, is operated primarily by the USGS; however, funding to operate the network is provided by the USGS and about 1,400 Federal, State, Tribal, regional, and local partners. Additional streamflow information can be accessed at https://www.usgs.gov/water-resources/ groundwater-and-streamflow-information/streamflowmonitoring?qt-science_support_page_related_con $=0 \# q t-$ science_support_page_related_con.

\section{References}

U.S. Geological Survey, 2021a, Groundwater and Streamflow Information Program: U.S. Geological Survey web page, accessed May 2021 at https://www.usgs.gov/waterresources/groundwater-and-streamflow-information.

U.S. Geological Survey, 2021b, Map of real-time streamflow compared to historical streamflow for the day of the year (United States): U.S. Geological Survey digital data, accessed May 2021 at https://waterwatch.usgs.gov/?id= ww current.

U.S. Geological Survey, 2021c, USGS water data for the Nation: U.S. Geological Survey National Water Information System database, accessed May 2021 at https://doi.org/ 10.5066/F7P55KJN.
—By Xiaodong Jian, ${ }^{l}$ David M. Wolock, ${ }^{1}$ Harry F. Lins, ${ }^{2}$ Ronald J. Henderson, ${ }^{l}$ and Steven J. Brady ${ }^{l}$

'U.S. Geological Survey.

${ }^{2}$ Emeritus scientist, U.S. Geological Survey.

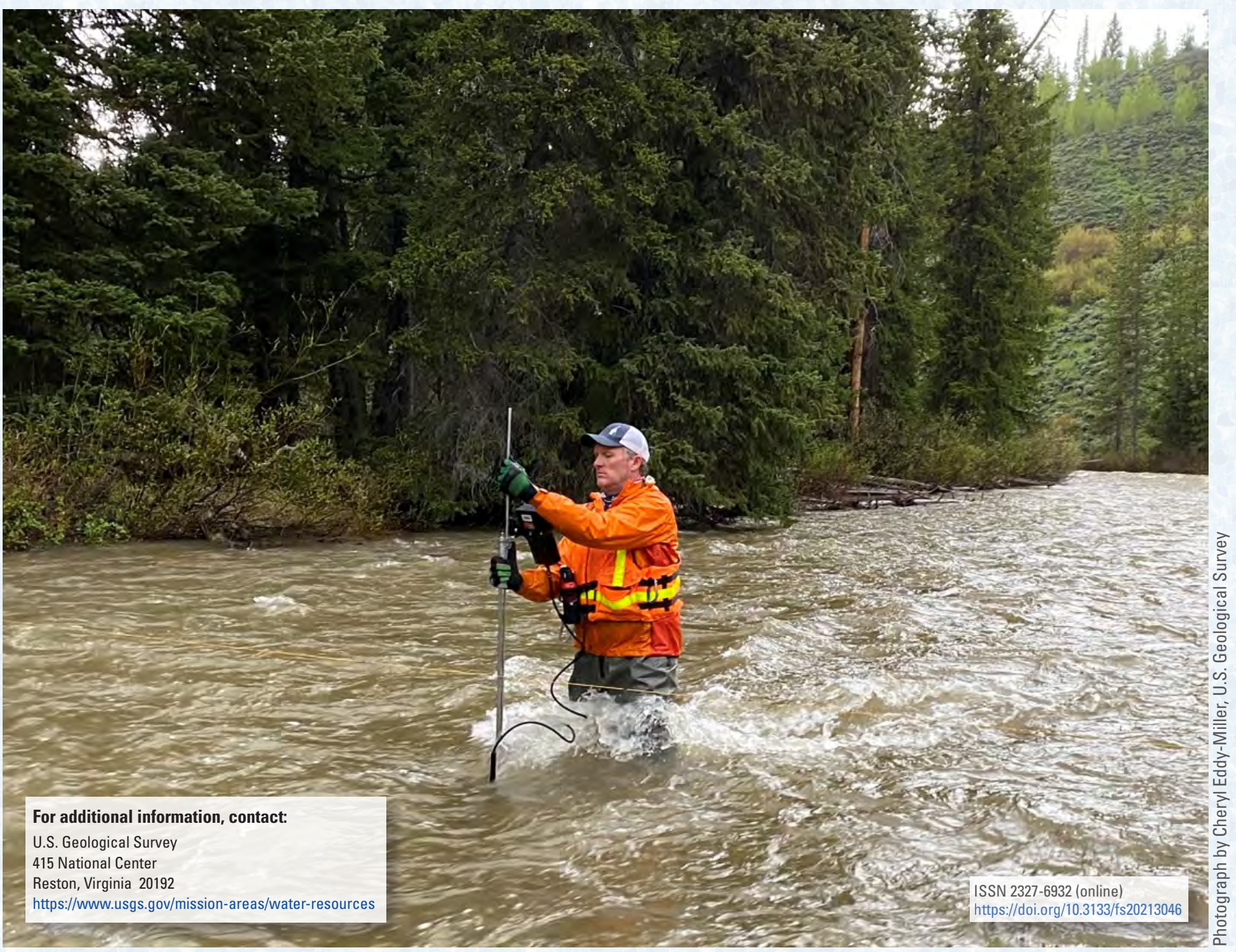

